\title{
ENCYCLOPAEDIA IRANICA
}

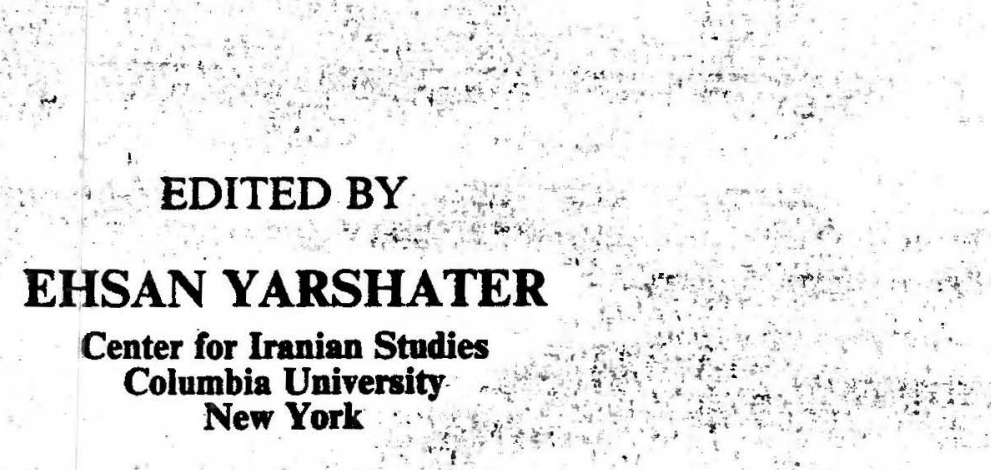

Volume V

FASCICLE 8

CLOTHING IX-COFFEE 
men dressed in Western style in the street. Some even adopted the headband ('eqāl) in imitation of leftist Arabs, but it was unpopular, and they soon abandoned it.

For women the situation was far more difficult. In the mid-1970s many rural families had migrated to the major cities, particularly Tehran, in search of employment. Most were unskilled, uneducated, and traditional in their outlook and convictions. After the Revolution, encouraged by religious leaders who had become government officials, women from this group harassed women who were not wearing the veil in public. Many educated women, particularly university students, had adopted traditional dress associated with Islam as a symbol of opposition to the Pahlavi regime, and the mass demonstrations during the Revolution had included large numbers of such women wearing black čădors (Plate CXXVII). But they had not expected to be forced to wear them after the Revolution; they staged a few brief protests, which, however, were met with insults and physical threats. As the state gradually consolidated its power, all women were forced to adopt the "Islamic" mode of dress in public. It consists of a loose gown covering the entire body in such a way that all curves, including the breasts, waist, and calves, are hidden. Only the hands, from fingertips to wrists, and the face are not covered by this garment. The head and neck are to be entirely covered either by a black čádor or a thick scarf (meqna' $a$ ). If the distance between the ground and the hem of the dress is greater than ten inches the calves of the legs, already swathed in thick black stockings, must be further hidden under full trousers. These requirements have been met with the same reluctance and resistance that greeted Reżā Shah's enforced ban on the same kind of clothing.

Many men still wear jackets and trousers, though most omit neckties.

Bibliography: F. Ādamīyat, Andiša-ye tarraqi wa hokümat-e qānün. 'Așr-e Sepahsālär, Tehran, 1351 Ṡ./1973. 'A. Ādarì, ed., Täriǩk-e moșawwar-e Reżā Säh-e kabir, Tehran, 1345 Š./1976 (useful for illustrations). M.-H. Adīb Heravī, Hadiqat alrażawìya, Mašhad, 1327 Š./1948. Moḥammad-Hasan Khan E'temād-al-Salțana, Čehel säl tärịk-e Irän dar dawra-ye pādšähi-e Näser-al-Din Šăh I. al-Ma'äter wa'l-ätär, ed. İ. Af̌̄ār, Tehran, 1363 Š./1984. M. Farrokk (Mo'tașem-al-Salțana), Käạterāt-e siāai-e Farrok , ed. P. Lavāšānī, Tehran, 1347 Š./1968, pp. 388, 391, 395. N. Sayfpūr Fāțemī, "Reżā Šāh wa kūdetā-ye 1299," Rahāvard 7/23, 1368 Š./1989, pp. 160-80. M. Moḱber-al-Salțana Hedāyat, Käteräto katarät, 2nd ed., Tehran, 1344 Ś./1965, p. 407. M. Kāẓemī, Rūzgäro andišahā, Tehran, 1350 Š./1971. N. Keddie, Roots of Revolution. An Interpretive History of Modern Iran, New Haven, Conn., 1981. 'A. Mas'ūdī, Ettelēā'ät dar yak rob'-e qarn, Tehran, 1950 S../1971. 'İ. Șadīq, Yādgär-e 'omr II, Tehran, 1345 S./1966. S. Šafā, Gäh-näma-ye panjāh säl šăhanšāhi-e Pahlavī I, n.p., n.d. J. Šahrī, Gūša-i az tärīk-e ejtemāì-e Tehrän-e qadìm I, Tehran, 1357
Š./1978. R. M. Savory, "Social Development in Iran during the Pahlavi Era," in G. Lenczowski. ed., Iran under the Pahlavis, Stanford, Calif., 1978. pp. 85127. F. Stark, The Valley of the Assassins. London. 1934, tr. 'A.-M. Sākī as Safar-näma-ye Alanūit. Lorestän w'a Iläm, Tehran, 1364 Š./1985. D. Wilber. Riza Shah Pahlavi. The Resurrection and Reconstruction of Iran, Hicksville, N.Y., 1975. E. Yaḡmā'ì, Kär-näma-ye Reżä Säh-e kabirr, Tehran, 2535=1355 Š./1976, pp. 170, 178, 216, 499. E.Žozef,"Rokn-alDīn Moḱtār . . ," Rahāvard 7/23, 1368 Š./1989.pp. 274-75.

('Ali-Akbar Sa'idi Sirjāinì)

$$
\begin{aligned}
& \text { xii. Qajar and Pahlavi Milttary Clothing. See } \\
& \text { MIlitary }
\end{aligned}
$$

\section{xiii. Clothing in Afghanstan}

The medley of tribal and ethnic populations in the diverse landscape of Afghanistan live mainly in rural towns and villages and nomadic camps. Hardly 5 percent lead urban lives. Traditional clothing reflects these geographic and residential variations and also serves to express individual and group identity, social and economic status, stages of the life-cycle, and changing sociopolitical trends, which ultimately lead to new styles, as well as to exchanges of clothing types (L. Dupree, pp. 238-47). Although terminology for all items of Afghan clothing varies widely, the central role of dress in Afghan culture is clear from the fact that new garments are essential for family, religious, and seasonal celebrations.

Headgear. The most diagnostic item of clothing is headgear, and even the ubiquitous turban (Pers. langötä, dastär, Pashto pa!kay, pagri $i$, which can vary in length from 3 to $6 \mathrm{~m}$, takes on distinguishing characteristics, depending on the arrangement of folds ( $L$. Dupree, pp. $71,162)$. White cotton is the most common turban cloth. though certain Pashtun groups prefer black and prestigious silk turbans tend to be woven in muted grays, browns, and pinks (Plates CXXVIII, CXXIX). Whatever the material, the longer the turban, the more fashionable the man. A young boy signals the coming of manhood by ceremoniously donning a turban. The easily recognizable shapes and decorative designs of the caps (Pers. koläh, Pashto kölay) worn under turbans are also distinctive indicators. Cylindrical silkembroidered caps distinguish the Uzbek and Tajik (see $x v$, below), fitted skullcaps of quilted chintz and felt (barrak) the Hazara (see xiv, below), and the famous cylindrical caps embroidered with gold and silver thread (goläbatūnī) the Pashtun of Qandahār; foldable caps encrusted with shiny colored-glass beads (marīdärä) are also made in Qandahār (N. H. Dupree, 1977 , p. 286). The Baluch set round mirror fragments (šiša) into their designs (see xviii, xix, below). Conical caps of wheat straw (druzaw kōolay) are unique among the Šinwārī eastern Pashtun, as are the small, round felt caps found in the high mountains of the

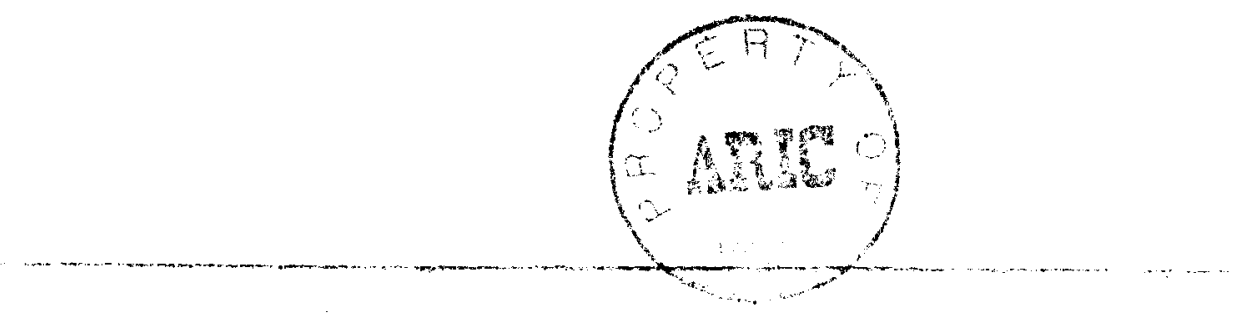


northeast. Other male headgear includes busby-like shapes (tilpak) made from sheepskin, worn by the Turkmen (L. Dupree, p. 182; see xxvi, below), round fur-trimmed hats and quilted hats with earflaps worn by the Kirghiz (Dor and Naumann), and flat-topped woollen caps with rolled rims worn in Nūrestān (pakōl generally; sukokuř in Kāmvīrī; Michaud, 1980, ill. 91). The modified cylindrical hat made from Persian lamb (qarakoli), which had distinguished all educated urban men since the beginning of the 20th century (Charpentier, 1977), is currently out of fashion.

Head coverings for all women are prescribed in Islam. Most women in traditional Afghan communi-

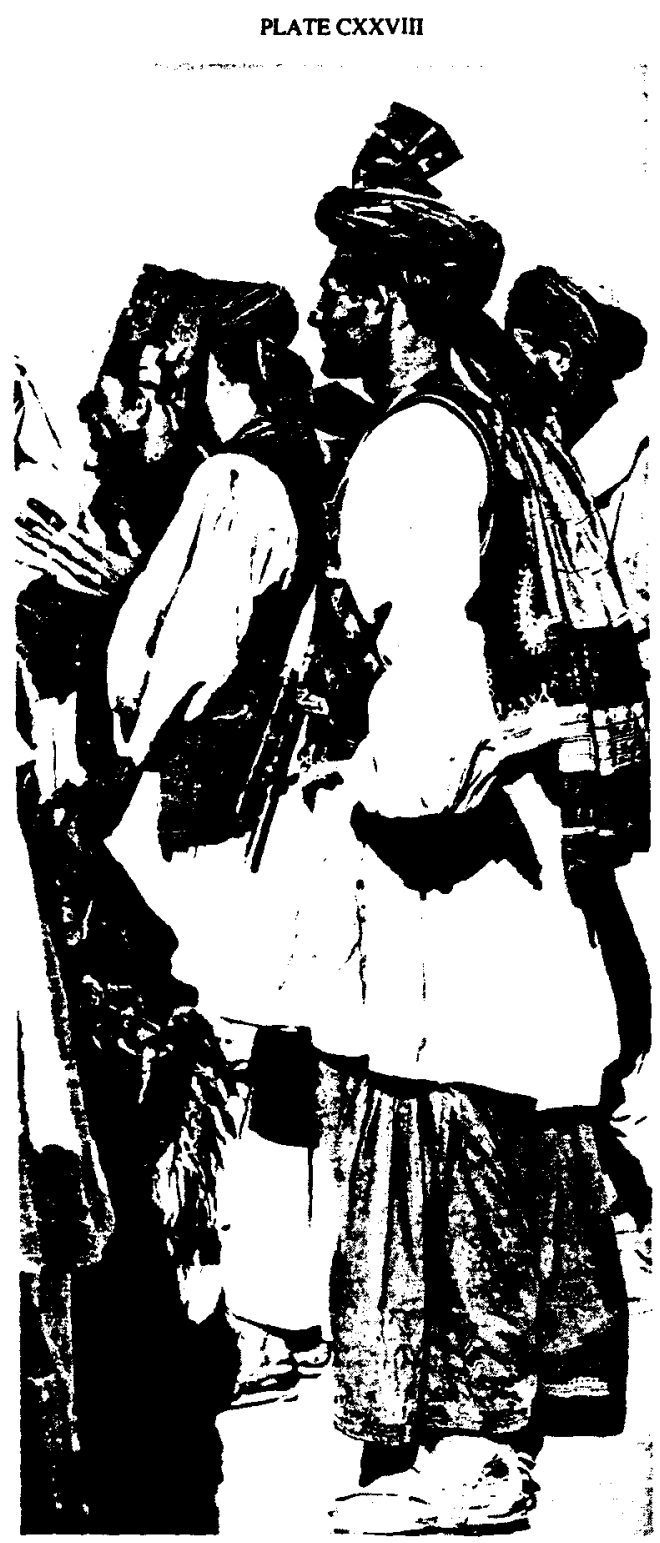

Men of the Tara KEêl tribe of eastern Pashtun. Photograph courtesy of Josephine Powell. ties, therefore, wear variations of large or small rectangular headscarves, commonly called čădar (see ĊảDOR). with or without small hats similar to the men's koläh. The čädar is made of soft cotton, often but by no means always in a solid color. Among certain Pashtun tribeswomen the čădar is an ankle-length mantle resembling a cape, bordered with heavy gold embroidery (Michaud, 1980, ill. 67). In contrast to the čădar, the cádari is composed of a close-fitting cap from which finely pleated colored silk or rayon falls, completely enveloping the figure, with only an openwork embroidered or crocheted grid over the eyes (Nicod, ills. 57, 59). Another style, with a separate see-through face veil, is called böqrä (< Ar. borqo; Herat) and paranjī (Kondūz). All čādaris are primarily urban garments (N. H. Dupree, 1978). The most spectacular headgear is worn by Turkmen women. Although the shapes of these tall (up to $45 \mathrm{~cm}$ ) headdresses (Turkic bojmāq. Pers. qașabä) differ from group to group, as do the silk wrappings, silver studs, and festooned ornaments that decorate them, all mark major stages in the lives of their owners. The exuberant creations worn by brides are replaced by more modest versions once they become mothers, and after menopause the silver ornaments are set aside entirely (Stucki, 1978). Uzbek bridal headdresses, though similar, are not as elaborate ( $P$. Centlivres). Individual creativity is also expressed in the decoration of baby bonnets with a profusion of pompoms, feathers, baubles, and beads.

Garments. The basic costume for men, women, and children is made from lightweight cotton and consists of loose-fitting, long-sleeved shirts worn outside wide trousers (Pers. tanbān, ezär, Pashto partög) gathered on a drawstring (ezärband). The length of the men's shirt (perän, korta), which is typically collarless and buttoned at one shoulder (N. H. Dupree, 1977, p. 388), varies from region to region, from knee to mid-calf or even lower. The finely embroidered Qandahări shirt fronts (gara, ganda) are renowned.

Waistcoats (waskat) are universally popular and may be made of black and red velvet decorated with gold braid or embroidery, as found in Qandahār (called sadri) and among some Pashtun nomads, or fashioned from local materials, like barrak (see BARAK) in the Hazārajāt. Many men, however, prefer Western vests purchased, along with Western coats and jackets, from second-hand clothing bäzärs. Indigenous types of outer garment are also worn. They include dressed-sheepskin coats worn with the fleece inside, with sleeves (pöstin) or without (pöstinča), and often embroidered, a specialty in the Pashtun area around $\bar{G}$ azni. Throughout the north full-length, quilted or single-weight collarless robes, striped in multiple colors and with long sleeves covering the hands (jilak and capan respectively), worn with a cloth sash (kamarband), are made of silk and handwoven cotton (karbās; N. H. Dupree, 1977. p. 341). A typical Uzbek type of padded coat, of brown or dark-red cotton, slips over the head and fastens at one side of the neck (gopiča). Elaborately embroidered short-sleeved felt coats ( $k u ̈ s a y)$ are worn 
PLATE CXXIX



Scene at the market of $\bar{A}_{q}$ Koprūk, near Mazär-e Šarīf in western Afghanistan. Photograph courtesy of Josephine Poweil. 
by the Pashtun in Paktiāa. Woollen shawls (čadar, Pashtu pat $\bar{u})$ are also popular with men in winter.

Nūrestāni dress is the most distinctive in Afghanistan. Men wear white woolen trousers, reaching just below the knee (vit in Kämvīrī. spoken in Kāmdeš), over long black leggings like puttees (pätaw), which, aside from the knitted wool stockings decorated with traditional designs of the Hazāra, are the only leg coverings rnade in Afghanistan. Prized silver-studded belts (mäläa niśs $\widetilde{e}$ ) for daggers (kätra) are also unique to Nūrestān (L. Dupree. p. 143). Nūrestāni women sometimes wear leggings under long, full skirts or robes ( $b \bar{a} z i i)$ gathered at the waist with woven belts (nisite) and embellished across the back of the shoulders and down the sleeves with a combination of red and black embroidered appliqués found nowhere else in Afghanistan (L. Dupree, p. 234).

Elsewhere, although women's dress styles conform to an overall pattern similar to that of men, differences in the length of the dress; the cut, drape, and fullness (up to $20 \mathrm{~m}$ ) of the voluminous trousers; the width of

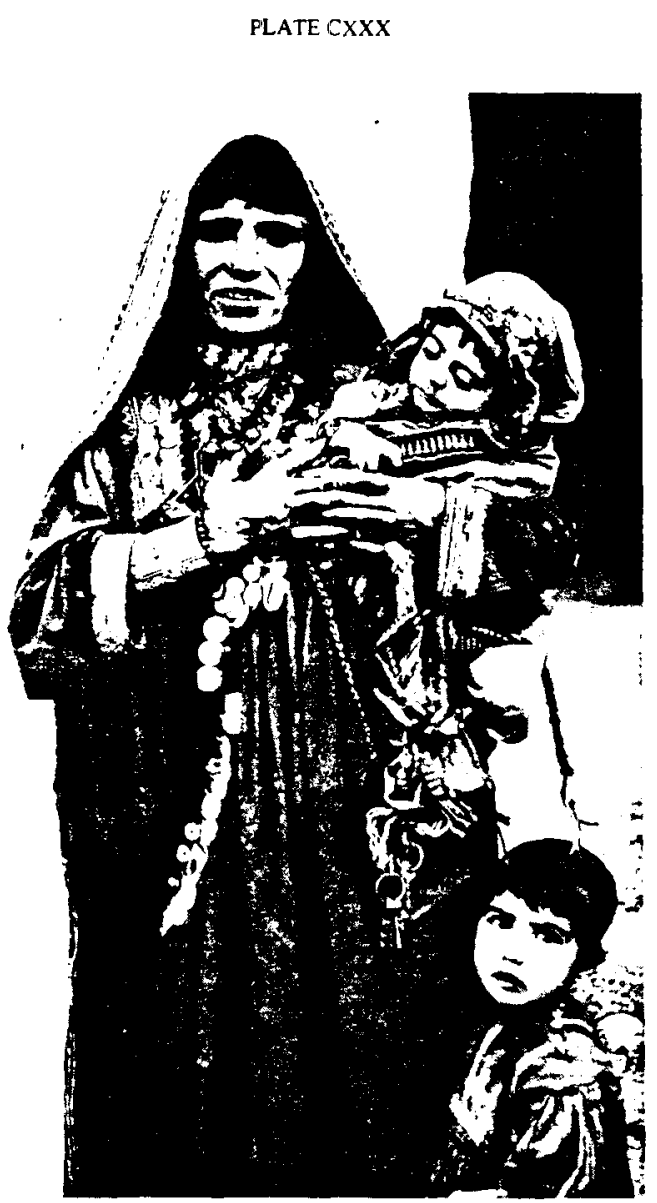

Wife of village headman, central Afghanistan, south of Taywāra in Gơr province. Photograph courtesy of Josephine Powell. the sleeves at the wrists and the trousers at the ankles: and fabrics-prints, textures, and decoration-are matters of great consequence to all women (Plates CXXX, CXXXI). In contrast to men's clothing, which is generally tailored in bäzärs, most women's clothing is hand-or machine-stitched at home. Especially among the eastern Pashtun the high-waisted bodices of the dresses, the flaring elbow-length cuffs, and deep borders on the hems of skirts containing as much as $12 \mathrm{~m}$ of flowered cotton or velvet are covered with exquisite

PLATE CXXXI

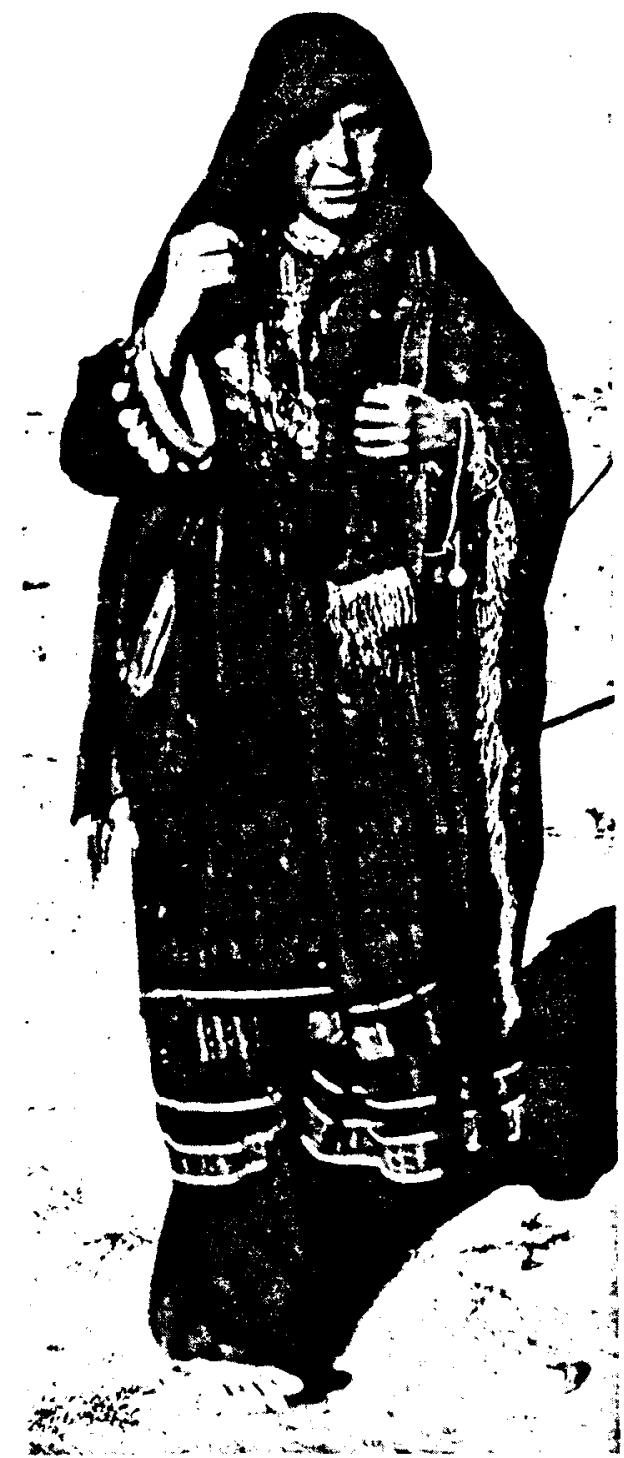

Nomad woman of the Tara Kël tribe of eastern Pashtun. Photograph courtesy of Josephine Powell. 
embroidery. Red, green, and royal-purple velvet are favored by the wealthier nomads, the mäldär.

In the cities, especially among the educated middle and upper classes, Western styles have predominated since they were introduced early in the 20th century as part of government efforts tomodernize (N.H. Dupree, 1988). Fashions have closely followed European models through the years, and, for women, Western dress came to symbolize emancipation (Rahimi, 1977). After the leftist revolution of 1357 S./1978 and during the subsequent years of Soviet occupation Western dress continued in vogue in Kabul. On the other hand, Afghan refugees in Pakistan, both men and women, wear traditional garments as symbols of their adherence to Afghan culture and Islam.

Footgear. Plastic shoes of every hue and style are popular throughout Afghanistan, but a variety of stout leather sandal (čaplï, Pashto čaplay), often soled with rubber cut from old tires, is also worn in many areas. Straw sandals (mazari čaplay) are found in Paktiā. Also distinctive are the ankle-high moccasins of Nưrestān ( $v a \bar{c} c o ́)$ and the knee-high leather boots, highheeled ( $\breve{a} a m u \bar{s} ;$ Nicod, ill. 29) or soft-soled ( $m a \bar{s} \bar{l}$ ), worn by northem Turkic speakers. The stout rubber overshoes (kalawš) worn to cover the másioutside the home are also commonly worn alone (Plate CXXVIII).

Jewelry. Jewelry, mostly of silver, is an important item in every woman's wardrobe, and generous sprinklings of silver beads, disks, coins, fastenings, and amulets ( $\left.t a^{\prime} w i d\right)$ are sewn onto clothing. Among some nomads, the eastern Pashtun in particular, these silver ornaments are typically combined with mirror work, gold and silver filament and braid, and elaborate beading, in addition to the fine embroidery described above.

Bibliography: M. and P. Centlivres, "Calottes, mitres et toques, Bulletin annuel du Musée et Institut d'Ethnographie de la Ville de Genève 11, 1968, pp. 11-46. P. Centlivres, "Les Uzbeks du Qattaghan," Afghanistan Journal 2/1, 1975, pp. 28-36. C.-J. Charpentier, "The Making of Karakul-Caps," Afghanistan Journal 4/2, 1977, pp. 76-78. R. Dor and C. Naumann, Die Kirghisen des afghanischen Pamir, Graz, 1978. L. Dupree, Afghanistan, Princeton, N.J., 1980, pp. 238-47. N. H. Dupree, An Historical Guide to Afghanistan, Kabul, 1977. Idem, "Behind the Veil in Afghanistan," Asia 1/2, 1978, pp. 10-15. Idem, "Victoriana Comes to the Haremsarai in Afghanistan," in P. Bucherer-Dietschi, ed., Bauen und Wohnen am Hindukush, Liestal, Switz., 1988, pp. 111-49. J. Graham and H. Sandys, The Decorative Arts of Central A sia, London, 1988. A. Janata, "Ikat in Afghanistan," Afghanistan Journal 5/4, 1978, pp. 130-39. C. M. Kieffer and G. Redard, "La fabrication des chaussures a Bamyan," Acta Orientalia 31, 1968, pp. 47-53. A. Legat, "Changes and Continuities in Women's Status and Clothing in Urban Afghanistan," in D. G. Hatt, ed., Ethnicity. The Role of Group Identification in Social Change, Calgary, Can., 1978. A. Leix, "Trachten der Nomaden Turkestans,"
CIBA-Rundschau 54, Basel, 1942, pp.1986-2001. R. and S. Michaud, Caravans to Tartary, London, 1978. Idem, Afghanistan, London, 1980. M.-L. Nabholz and P. Bucherer-Dietschi, eds., Textilhandwerk in Afghanistan, Liestal, Switz., 1983. M. R. Nicod, Afghanistan, Innsbruck, n.d. F. Rahimi, Women in Afghanistan, Liestal, Switz., 1986. K. E. Seraj and N. H. Dupree, The KES Collection of Vintage Photographs, New York, 1979. A Stucki, "Horses and Women," Afghanistan Journal 5/4, 1978, pp. 14049.

(NANCY HaTCh Dupree)

\section{xiv. Clothing of the Hazäa Tribes}

Hazāra clothing has not been studied systematically; only sporadic evidence can be found in literature, photographs, and major museum collections. Much of the information given here is based on the author's ethnographic work among the Hazāra in 1953-55 and in the Danish National Museum collection in 1948 and 1953-54.

The 19th century. Mountstuart Elphinstone, the father of Afghan ethnography, is apparently the earliest source on Hazāra clothing. He published one illustration (Elphinstone, pl. XII, facing p. 483; Plate CXXXII) with the brief comment "the dress of the men ... is distinguished by the rolls of cloth which they twist round their legs like the Uzbeks. The women wear long frocks of woollen stuff, and boots of soft deerskin, which reach to their knees" (p. 483). In the 1830s Alexander Burnes reported that Hazāra women of rank "go unveiled, and wear two or three loongees [lungies] on the head, like a tiara" (p. 175). He added that the Hazāras manufactured a fabric called "burruk" (see BARAK) from the wool of sheep.

The American general Josiah Harlan, who was also in Afghanistan in the 1830s, gave more detail. According to him, the manufacture of "berrick" was common throughout the Paropamisus mountains and among the pastoral tribes of Central Asia, but the best was made in Dāy Zangī in the southern part of Hazărajāt (p. 116). Of the Hazāra in particular he reported (pp. 128-30) that "the clothing of the poor or laboring class consists of a long frock made of the berrickiburrie and pantaloons of the same material fitting tight near the ankles. They wrap their legs with strips of the same material, about two and a half inches wide ... commencing at the ankle.... This arrangement is commonly adopted by couriers and other foot men who have occasion to perform long journeys.... Their feet are usually protected by sandals of straw. The higher orders use shoes of Cabul or Bulkh.... During winter ... those of Tatar proclivity use boots, or mashee [maši $]$ as they are called in 'Toorkie.' But for all pedestrian purposes at this season they use a most serviceable contrivance for the protection of the feet called sooklies [sokkli "lambskin"], which effectually and economically secure the wearer immunity from the influence of cold, frost, and snow! This sooklie is prepared from 